\title{
Severe ocular side effects of perhexilene maleate: case report
}

\author{
J. M. GibSON,' A. R. FIElder,' A. GARNER, AND P. MILlaC 3 \\ From the 'Department of Ophthalmology, University of Leicester School of Medicine, the \\ 'Department of Pathology, Institute of Ophthalmology, Cayton Street, London, and the \\ ${ }^{3}$ Department of Neurology, Leicester Royal Infirmary
}

SUMmaRY We report a case of perhexilene maleate (PEXID) toxicity in which the presenting feature was loss of vision secondary to chronic papilloedema. Vortex keratopathy similar to that seen in amiodarone keratopathy was present, and corneal and conjunctival biopsy findings are presented. To our knowledge this is the first case report of a keratopathy occurring in perhexilene toxicity. After withdrawal of the drug the papilloedema and keratopathy subsided, but some visual deficit remains. The properties of perhexilene maleate and other amphiphilic drugs are described, and the possible aetiology of vortex keratopathy is discussed.

Perhexilene maleate (PEXID) is an antianginal drug which has been in general use in Britain since 1975.' Several side effects have been associated with its use, including hypoglycaemia, ${ }^{2}$ hepatic dysfunction, peripheral neuropathy, ${ }^{4}$ and papilloedema. ${ }^{56} \mathrm{We}$ report the case of a patient who developed raised intracranial pressure and papilloedema while taking this drug and who presented with severe visual loss. Ophthalmic examination revealed a bilateral vortex whorl keratopathy indistinguishable from the verticillate keratopathy seen with chloroquine and amiodarone. The histopathological findings of corneal epithelial and conjunctival biopsy are presented, and other drugs with similar amphiphilic properties to perhexilene are discussed.

\section{Case report}

A 62-year-old Caucasian man attended the Ophthalmic Department of the Leicester Royal Infirmary with a one-week history of blurred vision affecting his right eye. Corrected visual acuity was $6 / 6$ in each eye, but the Goldmann perimeter showed enlargement of the blind spots in each eye and inferior field loss in the left. Fundus examination showed bilateral optic disc oedema and attenuation of the retinal arterioles. Plain skull and orbital $x$-rays and head CT scan showed no abnormality.

Correspondence to Mr J. M. Gibson. FRCSEd. Department of Ophthalmology. Clinical Scienees Building. Leicester Royal Infirmary. PO Box 65. Leicester LE2 7LX.
Three weeks later his corrected visual acuity had deteriorated to $6 / 18$ in the right eye and $6 / 24$ in the left eye. Slit-lamp examination revealed bilateral whorl-like epithelial keratopathy (Fig. 1). Bilateral optic disc oedema with choroidal folds and attenuated arterioles were found on fundus examination. A presumptive diagnosis of chronic papilloedema was made, and he was admitted to hospital for further investigation.

The patient was taking perhexilene maleate initially in a dose of $300 \mathrm{mg}$ daily for a week before reducing it himself to $200 \mathrm{mg}$ daily, and he had been on this dose for eight months at the time of presentation. He was

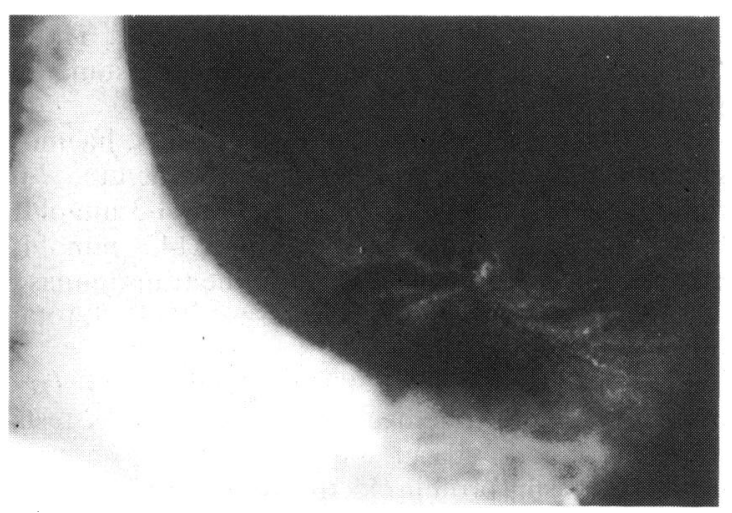

Fig. 1 High-power retroillumination slit-lamp photograph of left cornea showing vortex, whorl-like keratopathy. 


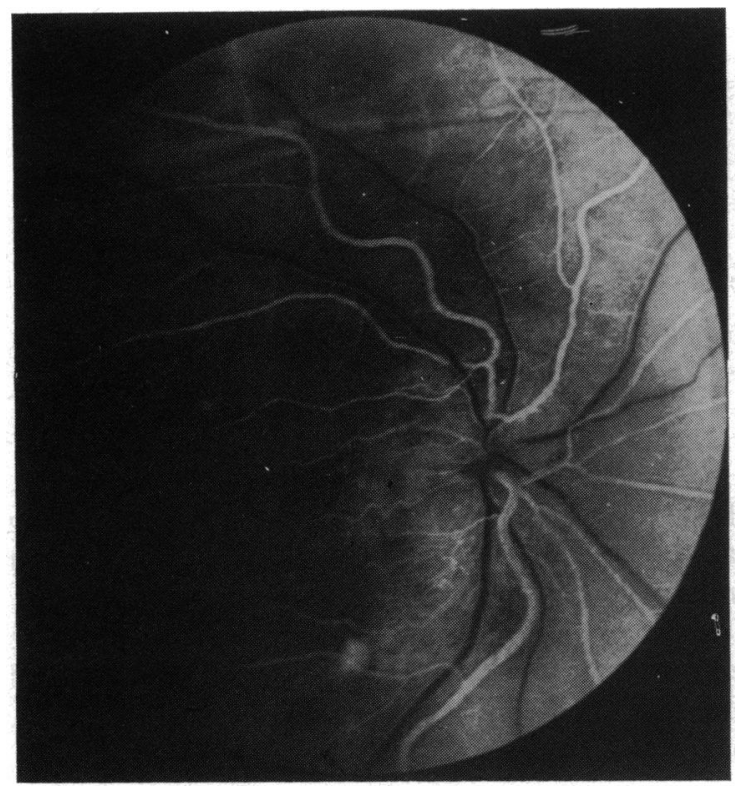

Fig. 2 Right fluorescein angiogram in early venous phase showing dilated capillaries on disc surface and choroidal fold superiorly.

also taking a thiazide diuretic and penicillamine for gout, but the patient had never taken amiodarone, chloroquine, or indomethacin.

The patient had suffered frontal headaches over the preceding few weeks, increased by bending down and coughing. There were no other neurological symptoms, but he had lost $13 \mathrm{~kg}$ in weight over the previous two months. Clinical examination failed to elicit any abnormal neurological or systemic signs. Intracranial pressure measured by lumbar puncture was raised at $320 \mathrm{~mm}$ cerebrospinal fluid. Fundus fluorescein angiography showed leakage from dilated optic disc capillaries in the late stage and confirmed the presence of choroidal folds (Figs. 2, 3). These findings supported the diagnosis of long-standing papilloedema.

Investigations gave the following results: haemoglobin $17 \cdot() \mathrm{g} / \mathrm{dl}$, erythrocytes $5 \cdot 66 \times 10^{12} / 1$, urea $7 \cdot()$ $\mathrm{mmol} / \mathrm{l}$, sodium $139 \mathrm{mmol} / \mathrm{l}$, potassium $4.3 \mathrm{mmol} / \mathrm{l}$, bicarbonate $23 \mathrm{mmol} / \mathrm{l}$, creatinine $142 \mathrm{mmol} / \mathrm{l}$, alkaline phosphatase $132 \mathrm{IU} / \mathrm{l}$, alanine transaminase $302 \mathrm{IU} / \mathrm{l}$, gamma glutamyl transferase $206 \mathrm{IU} / \mathrm{l}$, total bilirubin $19 \mathrm{mmol} / \mathrm{l}$.

Plasma viscosity was $1.89 \mathrm{cp}, \mathrm{VDRL}$ and Treponema pallidum haemagglutination (TPHA) tests were negative, and an autoantibody screen was negative. Plasma protein electrophoresis gave normal results. Urine microscopy showed no excess of birefringent material.

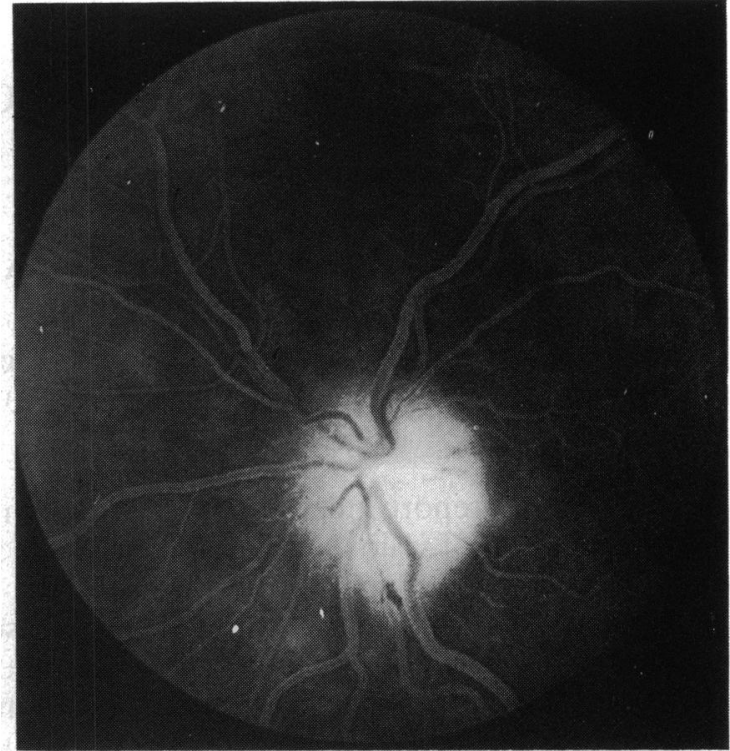

Fig. 3 Left fluorescein angiogram in late stage showing leakage of dye from dilated disc capillaries and small haemorrhage at disc margin. A choroidal fold can be seen at top of frame.

Cerebrospinal fluid (CSF) analysis: protein less than $0.1 \mathrm{~g} / \mathrm{dl}$, glucose $4.3 \mathrm{~g} / \mathrm{dl}$, Pandy test negative, VDRL and TPHA tests negative, erythrocytes $77 \times$ $10^{\circ} / 1$, leucocytes nil. The CSF sample was further analysed by the Department of Chemical Pathology at the National Hospital, Queen Square, London. No oligoclonal immunoglobulins were detected, and the proteins were consistent with moderate transudation of high-molecular-weight proteins across a damaged blood/CSF endothelium barrier.

Plasma perhexilene levels were assayed by gas chromatography, and the initial level was $3.3 \mathrm{mg} / \mathrm{l}$ (normal therapeutic range $(0 \cdot 1 \cdot 1 \cdot 0) \mathrm{mg} / \mathrm{l}$ ). Pattern reversal visual evoked responses showed reduced amplitudes and delayed $P_{2}$ latencies (right $168 \mathrm{~ms}$, left $145 \mathrm{~ms}$ ).

In the absence of any other causes of raised intracranial pressure a diagnosis of perhexilene toxicity was made and the drug withdrawn. A short course of systemic corticosteroids and chlorthalidone was started in an attempt to reduce CSF production. Nine days after withdrawal of the drug intracranial pressure had fallen to $140 \mathrm{~mm}$ of CSF, liver function tests were still abnormal, and the serum level of perhexilene was estimated as $3.1 \mathrm{mg} / \mathrm{l}$. Over the ensuing two weeks, however, the patient's visual acuity improved and tests of liver function partially improved.

Six weeks after drug withdrawal the vision had improved to 6/9 right and 6/12 left; papilloedema had 
subsided, but both optic discs showed temporal pallor with arteriolar attenuation. Liver function was still marginally abnormal. Six months after stopping perhexilene the liver function had returned to normal and the visual acuity was $6 / 9$ right and $6 / 12$ left. The visual fields have improved but there remains some loss to small targets inferiorly in the left eye. Conjunctival and corneal epithelial biopsies were taken shortly before the drug was withdrawn and light and electron microscopy performed.

\section{L.IGHT MICROSCOPY}

The conjunctival epithelium was generally thickened, showing squamous metaplasia and a loss of mucussecreting goblet cells. There were sporadic foci of cystic degeneration, and the flattened cytoplasm of residual cells surrounding rounded intraepithelial cavities were filled in part by variably fragmented and condensed debris of defunct cells. The corneal epithelium presented similar degenerative changes.

\section{ELECTRON MICROSCOPY}

Many conjunctival epithelial cells at all levels, but more especially in the basal cell layer, contained multiple electron-dense cytoplasmic inclusions which were either randomly distributed or in clusters (Fig.

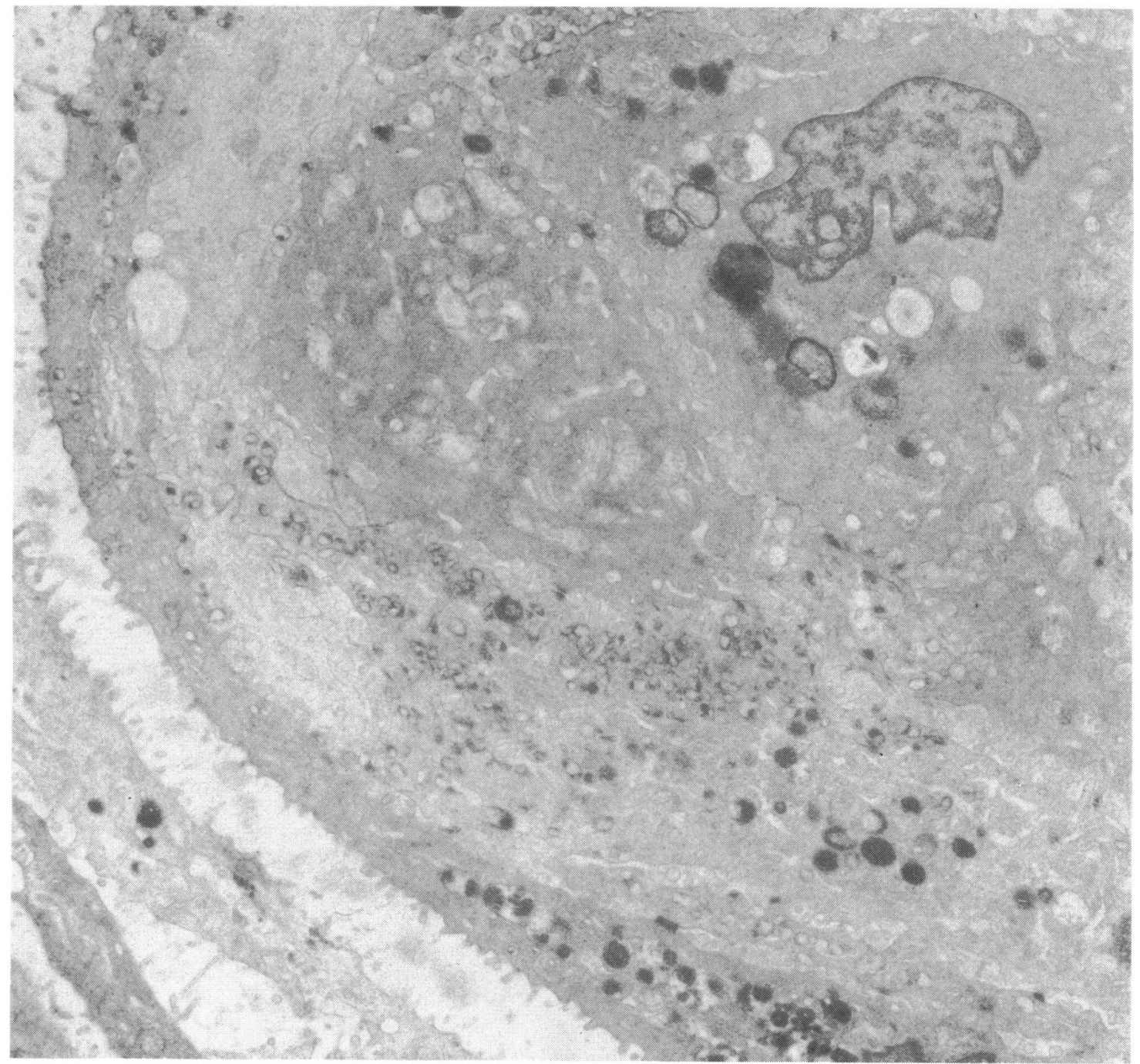

Fig. 4 Several epithelial cells in the conjunctiva include electron-dense bodies in their cytoplasm. (Transmission electron micrograph, $\times 78(0))$. 
4). Each inclusion was round or oval, with maximum diameters ranging from $(0.1$ to $1.0 \mu \mathrm{m}$; in some instances they were seen to be membrane-bound. Often the inclusions were amorphous or so electrondense as to make any internal structure unrecognisable (Fig. 5), but in some there was a well-defined concentric laminar arrangement (Fig. 6), each lamina measuring approximately $9 \mathrm{~nm}$ thick. Occasionally there was a less-ordered membranous structure (Fig. $5)$, and exceptionally there was a clear halo between the membranous whorl and the limiting membrane of the inclusion (Fig. 7); some were completely empty.
Mitochondria were numerous, and there was a normal complement of tonofilaments.

Structures corresponding to the intraepithelial cysts observed by light microscopy consisted of amorphous debris surrounded by the attenuated cytoplasm of adjacent intact cells (Fig. 8). (Comment: the intraepithelial inclusions are closely similar if not identical to those described in amiodarone keratopathy by D'Amico et al. ${ }^{7}$ It is reasonable to associate the cystic degeneration prevalent in the more superficial epithelial layers with the presence of the lipid inclusions in the basal cells.)

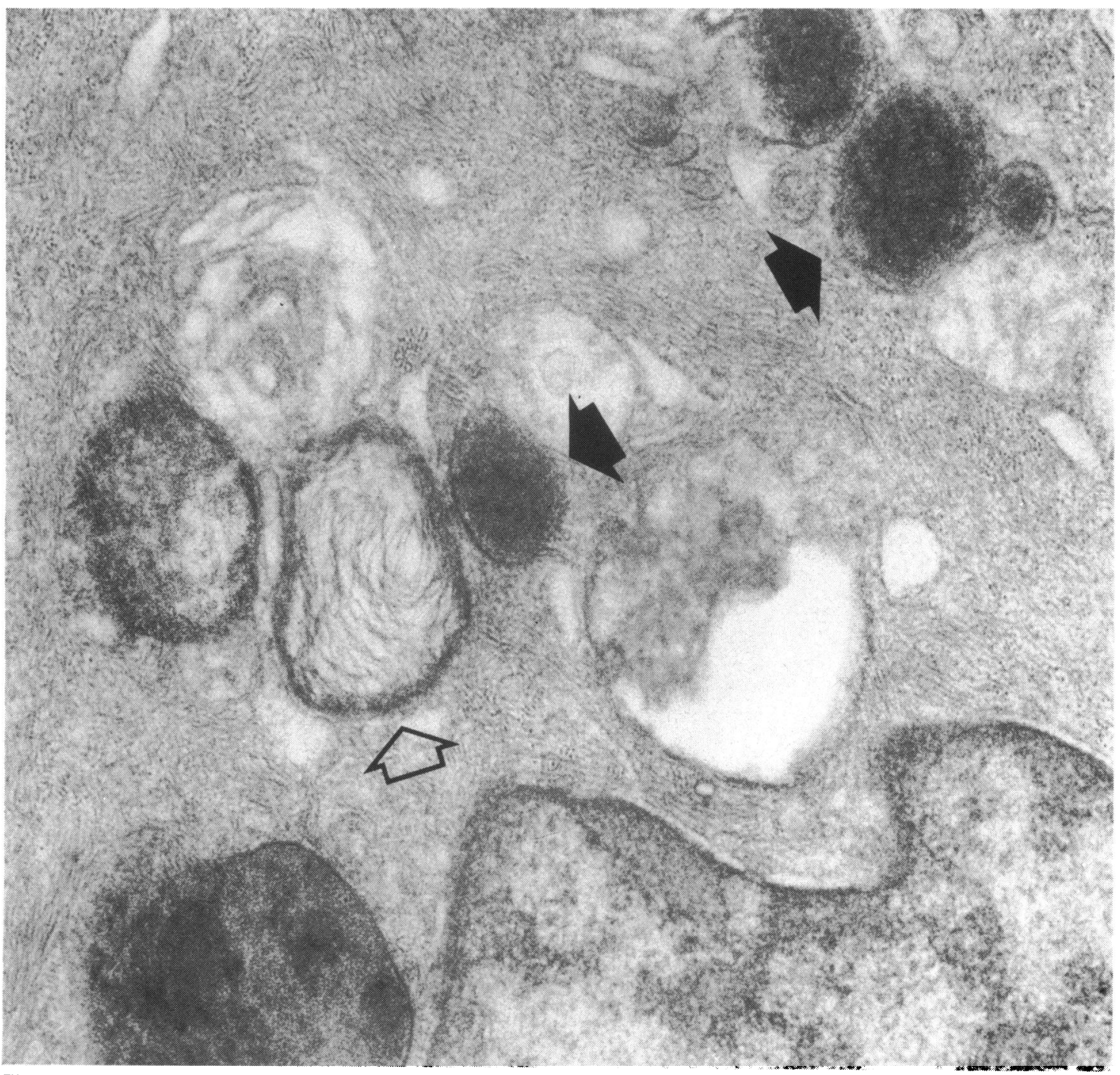

Fig. 5 Embedded in the cytoplasm of part of a conjunctival epithelial cell there are membrane-bound inclusions which are variably electron dense with no clearly resolvable infrastructure (solid arrows) or have an irregular membranous structure (open arrow). (Transmission electron micrograph, $\times 48(000)$ ). 


\section{Discussion}

The patient presented here suffered a long-standing (and probably permanent) visual defect as a result of chronic papilloedema following perhexilene administration. Perhexilene is an effective antianginal drug, recommended for use in patients with severe angina when other drugs fail to achieve adequate symptomatic control. ${ }^{x}$ Its mode of action is not fully understood, but exercise tolerance is improved." Perhexilene is rapidly and completely absorbed by mouth and is metabolised by the liver. Its half-time of elimination is $2-5$ days. ${ }^{11}$

Serious adverse side effects have been reported in patients taking perhexilene, including neuropathy, liver damage, and weight loss. Raised intracranial pressure and papilloedema may appear concurrently with neuropathy." So far there have been 10 associated deaths with hepatic toxicity. ${ }^{12}$ and recently the Committee on Safety of Medicines drew attention to these adverse reactions.
The peripheral neuropathy appears to be due to a demyelinating process. ${ }^{13}$ It is interesting to note, however, that clioquinol (iodochlorhydroxyquin), also an amphiphilic drug, has been implicated in causing subacute myelo-opticoneuropathy (SMON) in Japan. ${ }^{14}$ In this condition there is a demyelination of the optic nerves and spinal cord columns, though raised intracranial pressure is not usually a feature. Why perhexilene should occasionally cause raised intracranial pressure and papilloedema remains unexplained.

Ocular side effects of perhexilene are few, and there has been no previous report of corneal involvement. However, a case of keratoconjunctivitis sicca was reported by Turut et al. which improved after the perhexilene was withdrawn. ${ }^{15}$

The cause of the serious toxic reactions to therapeutic doses of perhexilene in some patients is not clear, but there is evidence that they may result from impaired drug metabolism. Singlas et al. "1" demonstrated that patients with peripheral neuropathy had

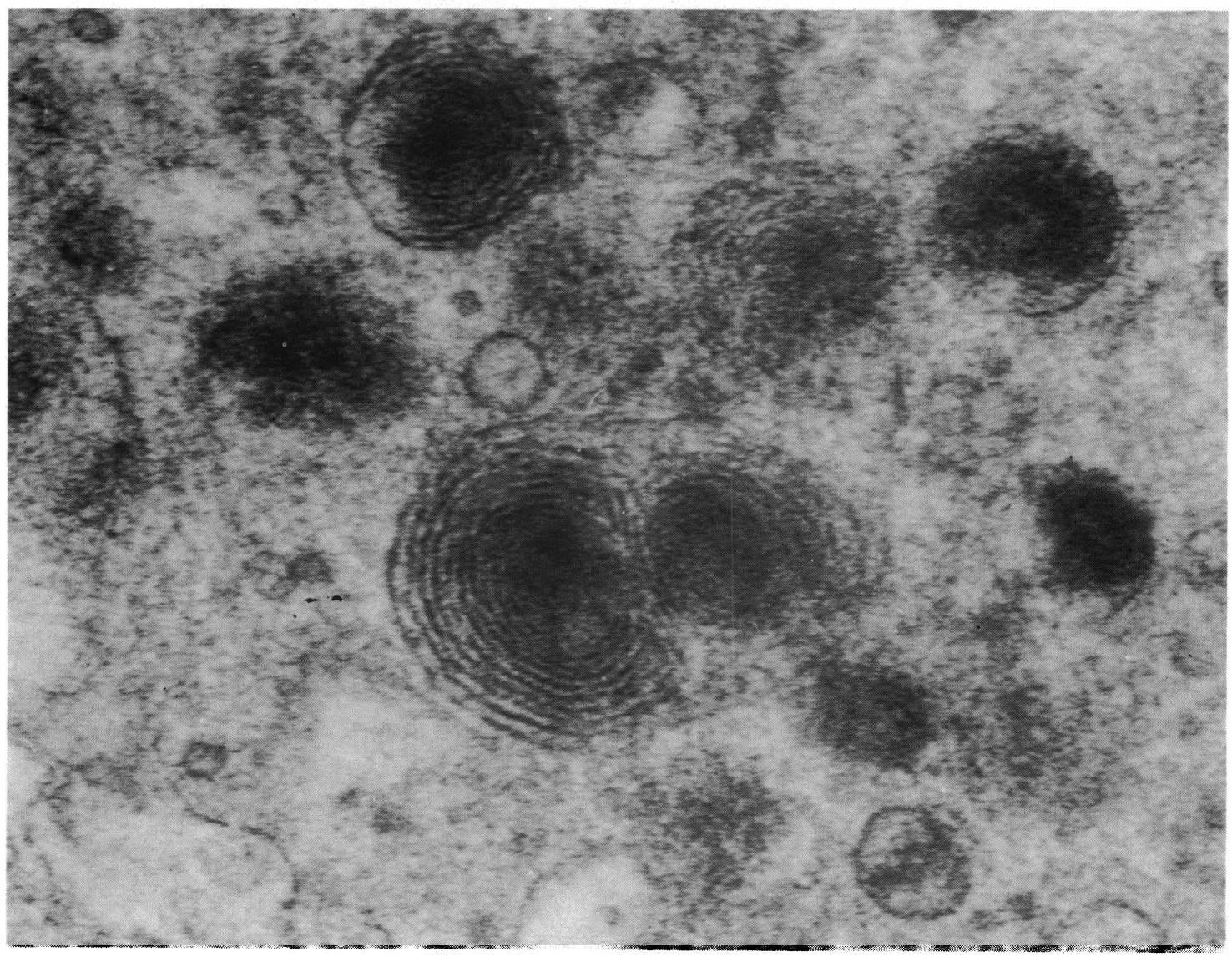

Fig. 6 Several of the inclusions in this cell have an organised concentric lamellar arrangement, with width of each lamellar averaging $9 \mathrm{~nm}$. (Transmission electron micrograph, $\times 78000)$. 
higher plasma perhexilene concentrations and longer clearance times than those patients taking the drug who did not suffer neuropathy. It is likely that our patient was unable to metabolise perhexilene normally, a condition reflected by his high serum concentration and slow rate of drug clearance. The ability to metabolise perhexilene efficiently appears to be an individual genetically determined characteristic. ${ }^{16}$

Perhexilene is a cationic amphiphilic compoundthat is, the hydrophilic and hydrophobic moieties are in very close proximity within the same molecule. Owing to their physicochemical properties amphiphilic drugs display high affinities to polar lipids and form tight but not irreversible complexes with the lipids. This results in the alteration of certain properties of the polar lipids such that they are less readily catabolised and accumulate within lysosomes. ${ }^{17}$ The resulting inclusion bodies resemble the pathological changes seen in some inherited metabolic disorders. Ultrastructurally the drug-induced phospholipidoses are characterised by membrane-bound residual bodies with a lamellated structure called myelin figures or multilamellar bodies. These have been observed in liver biopsy specimens from patients with perhexilene toxicity. ${ }^{18}$ They appear to be identical to the membrane-bound bodies which we have demonstrated in the conjunctival and corneal epithelium from this patient, and are identical to those described in amiodarone keratophy. ${ }^{7}$ It is not surprising, therefore, to find that the other drugs which have been implicated in causing verticillate keratopathy are all amphiphilic despite being pharmacologically different-for example, amiodarone, chloroquine, mepacrine, hydroxychloroquine, amodiaquin, and indomethacin. ${ }^{19}$ Furthermore similar intralysosomal inclusion bodies occur in Fabry's disease, a rare inherited metabolic disease in which there is a



Fig. 7 Of several vacuoles in this cell one contains a central whorled laminar structure (arrow). There is an unusually dense tonofilament content allied with a relative dearth of mitochondria. (Transmission electron micrograph, $\times 8300)$. 
deposition of glycolipid in the skin, kidneys, heart, gastrointestinal tract, and central nervous system as well as in the cornea. ${ }^{20}$

Besides corneal involvement it is well known that other ocular tissues can be affected by amphiphilic drugs. Thus studies have shown intralysosomal inclusion bodies in the retinal pigment epithelium of rhesus monkeys, ${ }^{21}$ while in rats similar changes have been induced by amiodarone. ${ }^{22}$ To our knowledge no retinopathy associated with amiodarone or perhexilene has so,far been described in man.

François ${ }^{23}$ first used the term cornea verticillata to describe the typical keratopathy involving the corneal epithelium in the characteristic vortex whorl. They have been comprehensively reviewed by Bron, ${ }^{24}$ who described the characteristic vortex patterns seen in toxic keratopathies, Fabry's disease, corneal iron lines, and in certain local corneal disturbances. $\mathrm{He}$ has suggested that the formation of the vortex pattern is due to the growth and repair patterns of the corneal epithelium. There is a continuous centripetal and radial slide of epithelial cells from the limbal epithelium. The vortex pattern is seen because affected cells have lost their transparency. What is not clear is why the vortex pattern is almost always in the lower half of the cornea. It is possible that this could be a mechanical or temperature-dependent phenomenon and develop more readily in the relatively cooler zone of the cornea. ${ }^{25}$

The case we describe is important in several

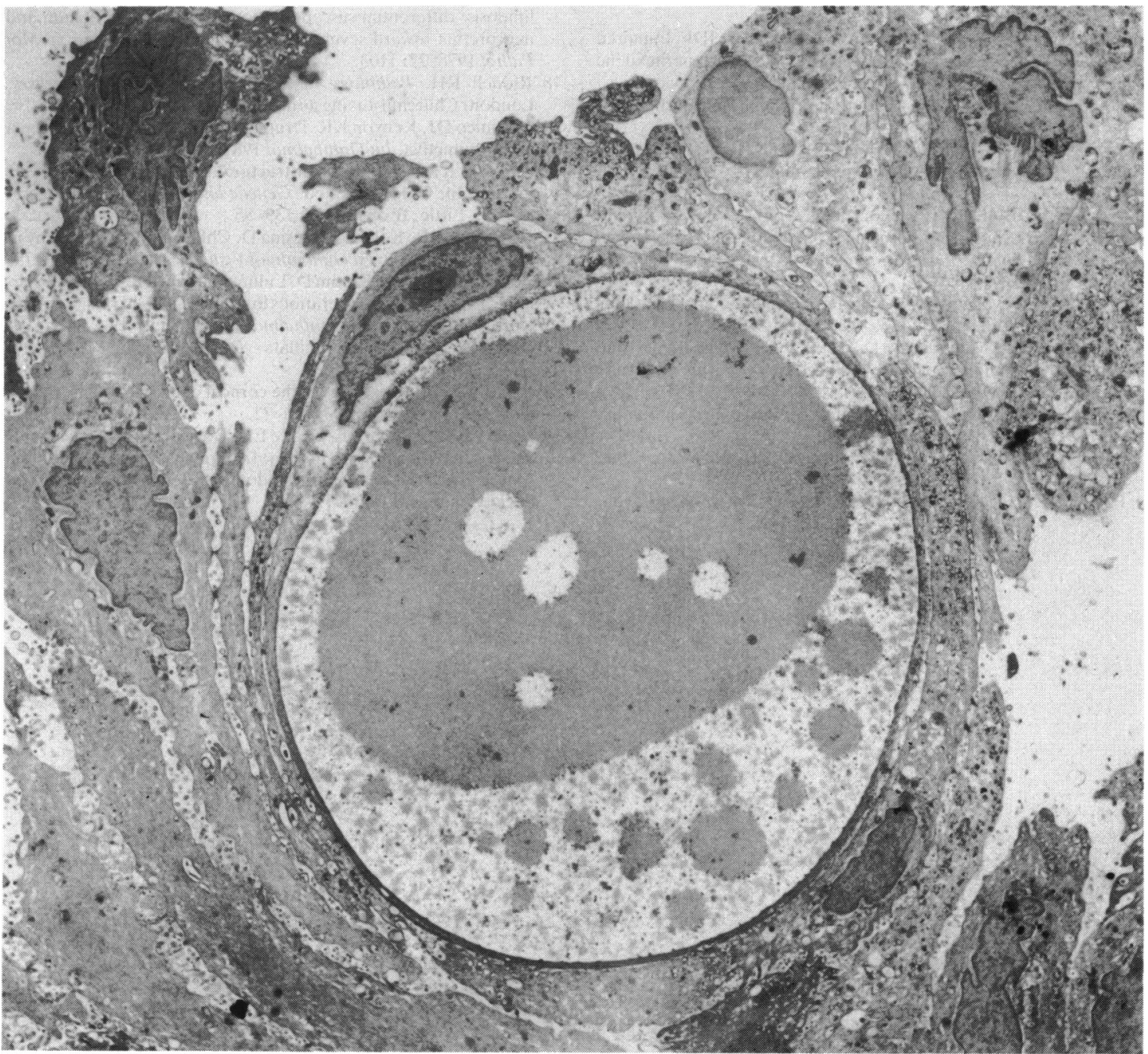

Fig. 8 A cystic cavity containing amorphous debris and surrounded by the attenuated cytoplasm of adjacent epithelial cells. (Transmission electron micrograph, $\times 3900$ ). 
respects. A patient taking perhexilene should be reviewed regularly, as indeed the manufacturer recommends, to screen for serious side effects. Raised intracranial pressure and papilloedema can lead to long-standing and perhaps permanent visual loss. The finding of a vortex keratopathy should therefore alert the ophthalmologist to the possibility of other potentially more serious side effects such as raised intracranial pressure and papilloedema.

We thank DrJ. Cooper, of the Coventry and Warwickshire Hospital, for performing the drug assays, Miss D. Callaghan for her photographic expertise, and Mrs J. Wood for her secretarial help. The electron micrographs were taken at the Institute of Ophthalmology and a sample of CSF was analysed in the Chemical Pathology Department at the National Hospital, Queens Square, London.

\section{References}

1 Shah RR, Oates NS, Idlc JR, Smith RL, Lockhart JDF. Impaired oxidation of debrisoquine in patients with perhexilene ncuropathy. Br Med J 1982; 284: 295-9.

2 Houdent CE. Wolf LM. Corriat A. Liver during perhexilene hypoglycaemia. Lancet 1977; ii: $1(128$

3 Lewis D. Wainwright HC, Kew MC. Zwi S. Isaacson C. Liver damage associated with perhexilene malcate. Gut 1979; 20: $186-9$.

4 Laplane D, Bousser MG, Bouche P. Touboul PJ. Peripheral neuropathics caused by perhexilene maleate. In: International symposium on perhexilene maleate. Amsterdam: Excerpta Medica, 1978: 89-96.

5 Hutchinson WM, Williams J, Gawler J. Papillocdema in patients taking perhexilene maleate. Br Med J 1978; i: 305.

6 Atkinson AB. McAreavey D. Trope G. Papillocdema and hepatic dysfunction apparently induced by perhexilene maleate (Pexid) Br Heart J 1980; 43: 490-1.

7 D'Amico DJ, Kenyon KR. Ruskin JN. Amiodarone keratopathy. Arch Ophthalinol 1981: 99: 257-61.

8 Anonymous. Perhexilene in angina pectoris. Drug Ther Bull 1976; 14: 97-8.

9 Pepine CJ. Schang SJ, Bemillar CR. Alteration of left ventricular responses to ischacmia with oral perhexilenc. Postgrad Med J 1973; 49 (suppl 3): 43-6.

10 Datcy KK, Bagri AK, Kclkar PN, Varma SR, Bhootra RK, Amin BM. Perhexilene maleatc: a new antianginal drug. Postgrad Med J 1973; 49 (suppl 3): 75-8.

11 Stephens W, Eddy JD, Parsons LM, Singh SP. Raised intracranial pressure duc to perhexilene malcate. Br Med J 1978; i: 21.

12 Committec on Safety of Medicines. Perhexilene malcate (Pexid): adverse reactions. Current Problems. August 1983; 11.

13 Bouche P, Bousser M-G, Pcytour MA, Cathala HP. Perhexilene malcatc and peripheral ncuropathy. Neurology 1979; 29: 739-43.

14 Shigematsu I. Subacute myclo-optico-ncuropathy (SMON) and clioquinol. Jpn J Med Sci Biol 1975; 28 (suppl): 107-64.

15 Turut $P$, Hache JC, Francois P. Arnott G. Les complications ophthalmologiques du Pexid. Bull Soc Ophtalmol Fr 1977; 77: $1(0) 3-7$.

16 Singlas E, Goujet MA, Simon P. Pharmacokinetics of perhexilene malcate in anginal patients with and without peripheral neuropathy. Eur J Clin Pharmacol 1978: 14: 195-201.

17 Drenckhahn D, Lullman-Rauch $R$. Drug induced retinal lipidosis: differential susceptibilitics of pigment epithelium and neuroretina toward several ampiphilic cationic drugs. Exp Mol Pathol 1978; 27: 1103.

18 Riddcll RH. Pathology of drug induced and toxic diseases. London: Churchill-Livingstone, 1982: 472-3.

19 D'Amico DJ, Kenyon KR. Drug-induced lipidoses of the cornea and conjunctiva. Int Ophthalmol 1981; 4: 67-76.

20) Kenyon KR. Ocular ultrastructural of inherited metabolic discase. In: Goldberg F, cd. Genetic and metabolic eye disease. Boston: Littlc, Brown, 1974: 139-85.

21 Rosenthal AR, Kolb H, Bergsma D. Chloroquine retinopathy in rhesus monkcy. Invest Ophthalmol Visual Sci 1978; 17: 1158-75.

22 Bockhardt $H$, Drenckhahn D, Lullmann-Rauch R. Amiodaroncinduced lipidosis-likc alterations in ocular tissues of rats. Albrecht . von Graefes Arch Klin Ophthalmol 1978; 207: 91-6.

23 François J. Cornea verticillata. Doc Ophthalmol 1969; 27: 235-51.

24 Bron AJ. Vortex patterns of the corncal cpithelium. Trans Ophthalmol Soc UK 1973; 113: 455-72.

25 Ficlder AR, Winder AF, Cooke ED, Bowcock SA. Arcus senilis and corncal temperature in man. In: Trevor-Roper PD, cd. The cornea in health and disease. London: Academic Press and Royal Socicty of Mcdicinc, 1981. 